\title{
HIGHER EDUCATION IN THE REPUBLIC OF BULGARIA AT THE CROSSROAD - PROBLEMS AND MEASURES TO PREVENT THEM
}

\author{
Desislava Petrova \\ Technical University of Gabrovo, Bulgaria \\ Lyubomir Lazov \\ Rezekne Academy of Technologies, Latvia
}

\begin{abstract}
This report identifies some of the problems of higher education in the Republic of Bulgaria related to the demographic crisis in the transition process and measures to overcome them. Emphasis is placed on the legislative framework, the rating system, the financing of higher education institutions and the science in them, the quality of training, the demand for staff from business and the supply of staff from universities, the admission of students and the offered forms of training. The analysis made by the authors is based on summarized data, which has been officially published, on the actual state of higher education in Bulgaria. Measures are proposed to overcome the problems, some of which are based on experience at the Technical University of Gabrovo.
\end{abstract}

Keywords: higher education, education, measures, rating, strategy.

\section{Introduction}

Education is a kind of personality improvement tool and an indicator of the progress of society. It is one of the areas with constant priority objectives for modernization. The process of education and training is in the interest of man, society and the state, involving the preservation and transfer of knowledge to future generations (Stoyanova, 2008). A number of reforms have been made in the educational system of the Republic of Bulgaria, related to changes in the structure and organization of the educational process, degrees of education, financing, accreditation, etc.

The main goals to be achieved by 2010 are:

- adopting systems with easily understandable and comparable educational degrees (bachelor, master, doctor);

- $\quad$ introduction of a two-cycle training system;

- building a credit system;

- $\quad$ promoting mobility by overcoming obstacles to its implementation;

- promoting European quality assurance cooperation; 
- $\quad$ promoting the European dimension in higher education.

All this was achieved with the help of reforms in the legislation: the Law on Higher Education (LHE), the Law on Development of the Academic Staff in the Republic of Bulgaria (LDASRB), regulations, regulations, decrees (Zakon za razvitieto na akademichniq sastav $\mathrm{v}$ Republika Balgaria, DV, № 38 ot 21.05.2010, № 81 ot 15.10.2010, № 101 ot 228.12.2010).

The purpose of the authors is to highlight the problems and find alternative solutions for higher education in Bulgaria, which is at a crossroads in the globalizing world. To achieve it, the following issues will be addressed: within the legislative framework of the country;

- $\quad$ the strategy for the development of higher education and statistics;

- a policy for the pre-emptive funding of certain scientific fields in order to meet the demand of certain business professionals;

- the demographic crisis in the country, which is a phenomenon throughout the European Union;

- providing quality education service to all citizens, regardless of gender, age, condition.

\section{Exposure}

\section{Legislative framework - strategy and statistics}

A "Strategy for the Development of Higher Education in the Republic of Bulgaria" has been developed and adopted, which clearly defines and distinguishes the main problems in the system. On the one hand, there is a growing need for more and more skilled personnel, on the other hand is Industry 4.0 and the new professions or the so-called "Professions of the future". Another determining factor is the high rates of scientific and technological development, the competitiveness of trained staff and access to higher education for citizens (http://old.government.bg/cgi-bin/ecms/vis).

According to the "Strategy for the Development of Higher Education in the Republic of Bulgaria for the Period 2014-2020", the main problems are caused by the significant discrepancy between the structure and profile of graduates and the dynamics of the labor market in Bulgaria and the European Union (EU). They are reduced to (Petrova \& Lazov, 2010):

- serious shortage of personnel in the field of engineering, natural sciences and pedagogical sciences;

- $\quad$ lagging behind in training in new professions needed for the green economy, high-tech and innovative activities;

- technological backlog in services and production; 
- $\quad$ the mismatch between expected competences and actual knowledge and skills.

Many manufacturing companies are looking for engineers and they are ready to pay a starting engineer with 1300 BGN of work (an amount above the national average by the end of 2019). in this area. It is the employers' initiative to seek contacts with higher education institutions at meetings, conferences and other forums in order to obtain the necessary human resources they need. They participate in the development of curricula for the majors and the writing of curricula in different disciplines. Here, students in real-world environments fulfill their obligations regarding student internships, the development of diploma papers and projects.

Universities, in their turn, are looking for new, attractive and necessary specialties for business and candidate students. This is because the candidates are few and the places in the universities are many. Evidence in this direction is that in the 1999/2000 academic year, 41 universities and 47 colleges operated in Bulgaria. As of January 31, 2011, there are 50 accredited universities, academies, colleges, etc., and now there are 52 accredited by the Register of Higher Schools of the Ministry of Education and Science (MES), developed on the basis of Art of the Higher Education Act (HEA). As of September 2019, there are 207,000 Bulgarian students in Bulgaria and 14,000 foreign students from 115 countries. The share of foreigners in our universities is about 6\%, according to EUROSTAT data. The largest is the proportion of students from Greece - 3600 (26\%), the UK - 2000 (14\%), Turkey - 1 400, Germany - 1 120, Ukraine - 700, etc. foreign doctoral students are 529, from Greece - 138, Turkey - 75, Kazakhstan - 50, etc. At the same time in Austria, which has a relatively the same population - 8.18 million people and the same number of students 241 thousand, there are 13 universities and 6 art colleges. An average of 12,700 students enrolls in an Austrian higher education institution, and about 6,000 in Bulgaria. One in every 200,000 people in Bulgaria falls in one higher education institution against 43,0000 in Austria. How is France? - 90 universities, 3 national institutes and 14 higher education institutions with more than 2 million student. In Spain - 43 public universities, 3 private and 4 Catholic with a total of 1.7 million students. Another major focus is the choice of major, and in the EU in 2018, almost one-third of the 19.6 million students have chosen to study: social sciences, administration and management, law. Of these, 11.9 million are enrolled in Bachelor's Degree Programs, and 7.7 million students upgrade to Master's Degree Programs. 
Petrova \& Lazov, 2020. Higher Education in the Republic of Bulgaria at the Crossroad Problems and Measures to Prevent Them

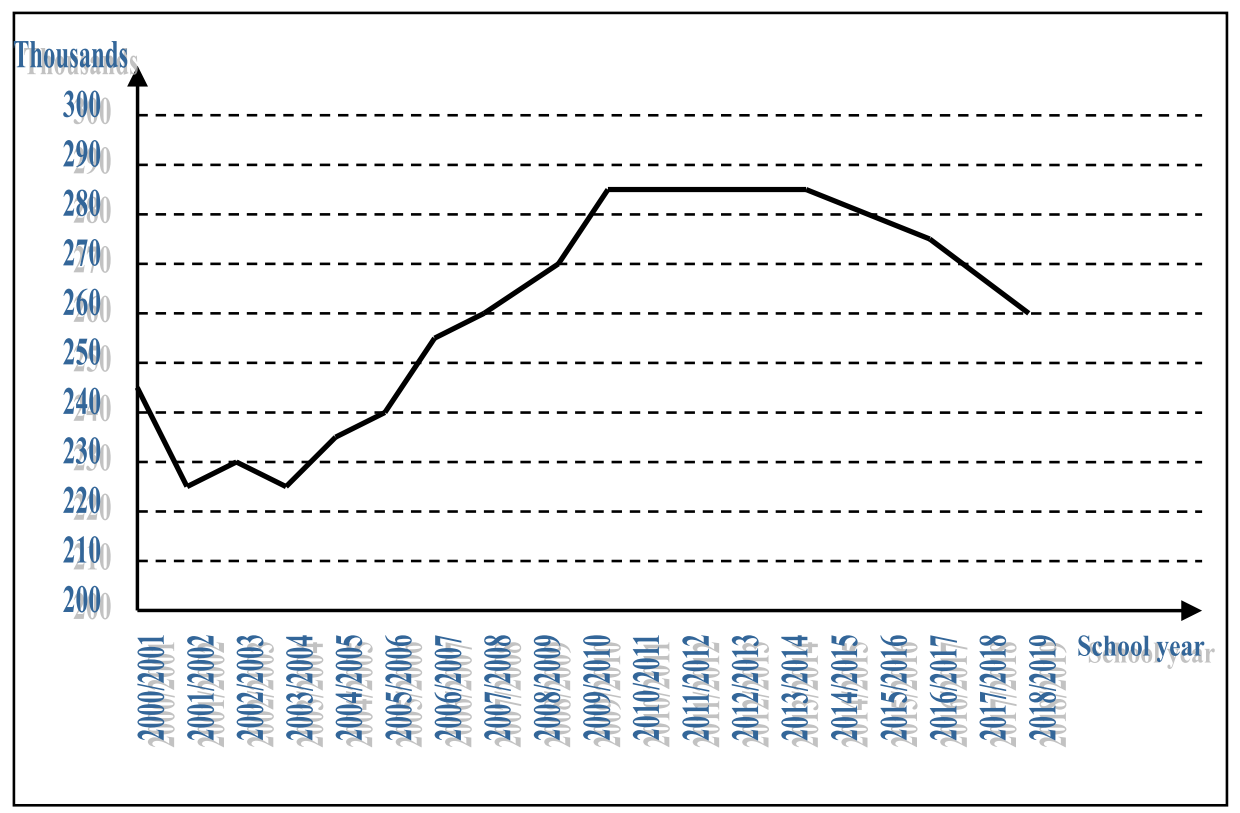

Figure 1 Students trained in program: a "Professional Bachelor", "Bachelor" and "Master" for the period 2000-2019

Brussels experts advise the Bulgarian government and the Ministry of Education and Science (MES) respectively to reform the system and reduce the number of institutions of higher education to 10 because European practice is 1 million per capita to have one university. The MES policy, in turn, does not support the decision to close universities, but rather to profile in technical, humanities, natural sciences, the arts, etc., to unite and unite in European education networks.

\section{A policy for the pre-emptive funding of certain scientific fields in order} to meet the demand of certain business professionals

The policy of the state is, with the help of the developed and effective seven year rating system, to finance with state subsidy the pre-eminent scientific branches and universities in the top places in the ranking with a higher state subsidy (Kartunov, 2015). It is worth mentioning here that the Technical University is ranked $2^{\text {nd }}$ in Mechanical Engineering, $3^{\text {rd }}$ in General Engineering and $5^{\text {th }}$ in Communication and Computer Engineering in this Ranking System and this is reflected in allotted state procurement by the directions and the corresponding financing from the state budget. For example, for 2019 at the Technical University of Gabrovo the subsidy was increased by nearly BGN 600,000 and increased by an average of $10 \%$ of the admission plan in these areas, projects in these fields of science were validated (Competence Center BG05M2OP001-1.002-0023 "Intelligent Mechatronic, Eco and Energy Saving Systems and Technologies" with budget 23,569,719 BGN, Center of Excellence BG05M2OP001-1.001-0008 "National Center for Mechatronics and Clean 
Technologies" with budget 69,184,530 BGN, Competence Center BG05M2OP001- 1.002-0006 "Quantum Communication, Intelligent Security and Risk Management (QUASAR)" with budget 13,500,000 BGN, Competence Center BG05M2OP001-1.002-0002 "Digitization of the economy in a Big Data environment" with budget 13,333,869 BGN).

The share of university graduates (aged 30-34) reached 32.1\% in 2015, which means that Bulgaria is on track to reach the national target of the Europe 2020 strategy of 36\%. There is a significant gender gap in higher education: the percentage of women is about 15 percentage points higher than that of men.

The employment rate of recent graduates has increased significantly, to $87.1 \%$ in 2018 , and now exceeds the EU average of $81.9 \%$. This is due to the improvement of labor market prospects. In 2015, 2016, 2017, 2018 and 2019, economics and administration and administration studied the highest share among university graduates $-29.7 \%$, followed by social and behavioral sciences (13.7\%), engineering and engineering professions (10.7\%), pedagogy and education (8.12\%) and healthcare (6.81\%). Computer science graduates (3.18\%), life sciences (0.83\%), mathematics and statistics $(0.16 \%)$ have the lowest shares. The share of higher education graduates in the social sciences, business and law is one of the highest in the EU, but with a downward trend. The share of higher education graduates in science, mathematics and informatics, as well as in health and well-being is one of the lowest in the EU, but is increasing.

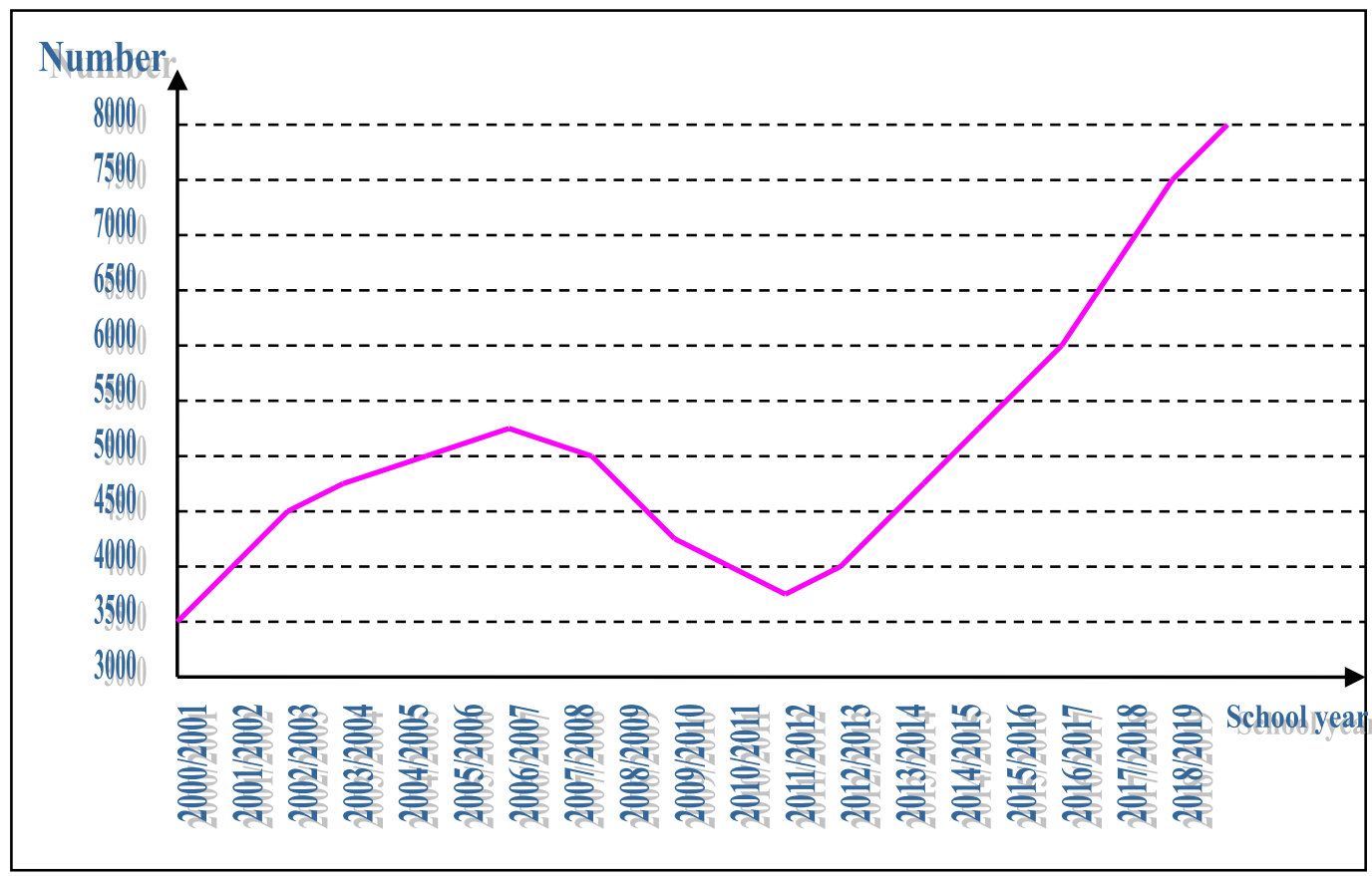

Figure 2 Students learning in educational and scientific degree "Doctor" 
Regarding the third degree of Doctor, there is an increase until 2007, followed by a decline until 2011 and after the reform in higher education with the entry into force after the promulgation of the Law on Development of the Academic Staff in the Republic of Bulgaria (LDASRB) growth. This increase in the number of Ph.D.s is due to the new law giving universities the opportunity to educate researchers, to be able to award doctoral degrees in the field, as well as to be able to appoint associate professors and professors". As of 2018, a system has been developed at the National Center for Information and Documentation with a Register of Academic Staff and the Defended Dissertation. As of January 2020, 4731 persons are registered in it, corresponding to the relevant scientific and metric indicators divided by names, organizations, professional field, scientific degree, date of appointment, date of diploma, etc., with 25 registered for the Technical University of Gabrovo.

The Higher Education Development Strategy 2014-2020 also outlines a number of key challenges, such as:

- insufficient funding;

- $\quad$ insufficient applicability of education in the labor market;

- $\quad$ insufficient links between training and research;

- difficulties in recruiting teachers and in their professional development;

- insufficient opportunities for lifelong learning;

- difficult access to higher education for vulnerable groups.

Challenges regarding the low applicability of the labor market are related to the mismatch between the skills of the graduates and the needs of the labor market, the lack of personnel in engineering and pedagogical sciences, the limited link between the curricula and the labor market, the need for more hands-on training and a lack of vocational guidance.

There are also challenges regarding the quality of Bulgarian higher education and its compatibility with the European higher education system, due to teaching methods lagging behind new trends, poor scientific performance in some areas, complex and inefficient accreditation procedures and evaluation of universities, as well as insufficient outgoing and poor inbound student mobility.

To address these challenges, the Higher Education Strategy proposes a series of measures within seven objectives:

- improving access to higher education and increasing the number of graduates of higher education;

- $\quad$ improving the quality of higher education;

- creating a sustainable and effective link between higher education institutions and the labor market;

- promoting research; 
- modernization of the management system and a clear definition of higher education institutions;

- $\quad$ increasing funding for higher education and science;

- $\quad$ overcoming the negative tendencies in the professional development of teachers in higher education and creating incentives for them.

In line with the Strategy, Bulgaria introduced a results-based model of financing higher education institutions, with the results shown in Figs. 1, 2 and 3. In 2014, $14.6 \%$ of the state funding for public schools was allocated on the basis of criteria designed to assess the quality and applicability of education in the labor market. This share has increased to $30 \%$ for the academic year 2016/2017, reaching 60\% in 2019/2020. Government funding is no longer predominantly based on the number of students enrolled in a specialty, but is determined on the basis of specific criteria for quality of training and compliance with labor market needs, accreditation and research evaluation of universities and employment suitability data of higher education graduates. In view of socio-economic priorities, 32 majors have been identified as 'priority areas' and 12 other areas have been considered 'protected' (ie important but not attractive to applicants). The list of priority areas includes mathematics, engineering, biotechnology, chemistry, energy, food technology, computer science, computer science and technology. Finally, the identified protected majors are predominantly in the field of philology (Korean Studies, Greek Philosophy, and Japanese Studies).

\section{Demographic crisis in the country, which is a phenomenon throughout the European Union}

Europe's population is aging. In six EU Member States, the age group between 5 and 18 years will shrink by at least $20 \%$ by 2040 . The other six Member States face a shrinking age range of between $10 \%$ and $20 \%$. At the same time, asylum applications submitted to the EU for the first time have tripled since 2013, with more than $80 \%$ of asylum seekers in 2015 under the age of 34. In 2017, as the flow of migrants into the EU increases, the number of candidate students increases. Europe's population is changing, and employment is also changing. Living and working in a technologically advanced and globalized economy requires people to acquire higher qualifications, knowledge and skills. A higher level of education is associated with a higher level of basic skills and responds to higher levels of employment. Recent graduates have an employment rate of $81.9 \%$ in 2015 , which is 11.1 percentage points more than holders of diplomas for upper secondary education or vocational training after high school. Therefore, improving skills, in particular for low-skilled groups and disadvantaged groups, is one of the main objectives of the New Skills Program. The MES now turns its policy to dual education, to promoting the opening of vocational schools in secondary education and in higher education. Policy mea- 
sures aimed at increasing the potential of education are a response to societal challenges and are implemented mainly in primary and secondary education (http://eur-lex.europa.eu/LexUriServ/LexUriServ.do?uri=COM:2010:2020:FIN: BG:PDF).

At higher education level, the percentage of graduates increased significantly in the EU in 2016, at 38.7\%. The EU has reached its target of $40 \%$ of university graduates in the population aged 30-34 by 2020. The level of qualification still varies between women and men, between births in the country and births abroad, and between regions and countries.

Higher education, as well as secondary education and post-secondary vocational programs, play a special role in preparing people for the labor market. In 2015, recent VET graduates had an employment rate of 73\%, and the employment rate of recent high school graduates was 61.2\% (Boeva, 2013).

Higher education has great potential to promote upward social mobility and to improve employment prospects. Policy measures to increase innovation and the applicability of higher education include personalized career guidance, follow-up of graduates, and work-based learning. Tracking the professional attainment of graduates is a practice in higher education institutions (Kartunov \& Petrova, 2009).

The rating system and policies in the sector are changing the behavior and strategies for the development of higher education institutions in the Republic of Bulgaria. With its first release, the rating system (2010) provides a reliable assessment and tool for differentiating financing. Since 2015, based on the information from the rating system with certain indicators, the admission into public universities is restructured. From the position in the Rating system comes the assessment, which includes indicators for educational, scientific activity and achievement of graduates. Changes in admission are aimed at admission of students in the priority vocational fields, for which there is an expected shortage in the labor market, and to higher education institutions with higher marks for quality and realization. Respectively, the funding is reduced and accepted in the professional fields, which have a higher share of the irrational demand for higher education and which have a lower rating. In the last 2 years (2016 and 2017), enrollment in public higher education institutions has been reduced by over 12,000 units annually. This reduction concerns in particular the destinations: "Economics" and "Administration and Management". 
SOCIETY. INTEGRATION. EDUCATION

Proceedings of the International Scientific Conference. Volume II, May $22^{\text {th }}-23^{\text {th }}, 2020.214-226$

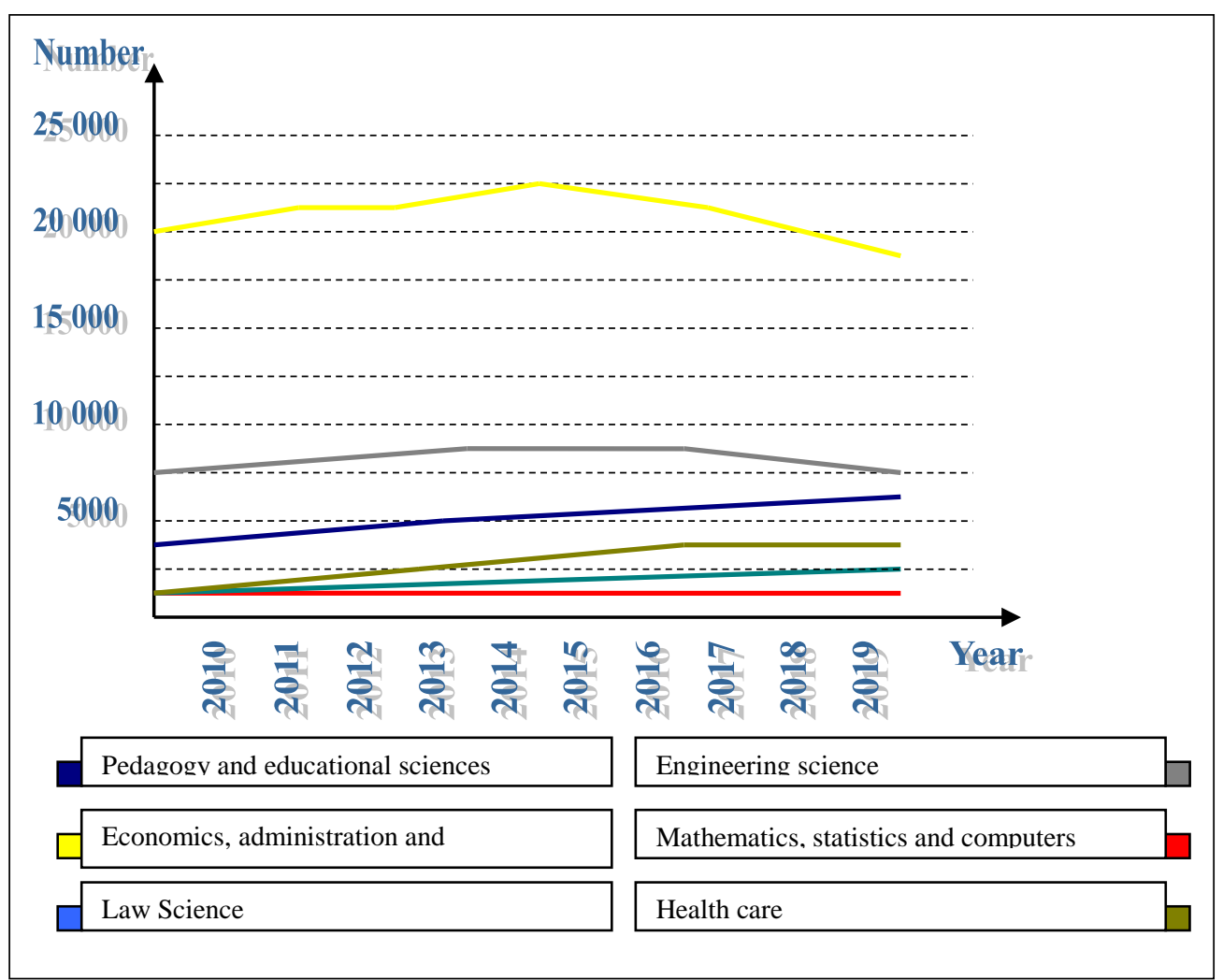

Figure 3 Number of university graduates by main areas (all levels of higher education), according to the National Statistical Institute, 2019

There is an irrational demand for higher education in these two areas of science. It is important to note that the professional fields are divided into 4 groups:

$1^{\text {st }}$ The most demanding occupational fields relevant to particular public sectors (mathematics, chemical sciences and physical sciences);

$2^{\text {nd }}$ Other priority professional areas;

$3^{\text {rd }}$ Directions for which there is no lack of demand on the part of the applicant students;

$4^{\text {th }}$ "Economics" and "Administration and Management", in which the reduction of admissions will continue even in the highly rated higher schools.

Let's look at the facts at the Faculty of Economics of the Technical University - Gabrovo presented in Table. 1 below: 
Petrova \& Lazov, 2020. Higher Education in the Republic of Bulgaria at the Crossroad Problems and Measures to Prevent Them

Table 1 Admission Plan by Year at TU - Gabrovo, Faculty of Economics

\begin{tabular}{|c|c|c|c|c|c|c|}
\hline $\begin{array}{l}\text { Professional Field / } \\
\text { Specialties }\end{array}$ & Coefficient & $\begin{array}{c}\text { Capacity } \\
\text { (Regular } \\
\text { training } \\
\text { /Distance } \\
\text { learning) }\end{array}$ & $\begin{array}{c}\text { Students } \\
\text { accepted } \\
2017 / 2018 \\
\text { (Regular } \\
\text { training } \\
\text { /Distance } \\
\text { learning) }\end{array}$ & $\begin{array}{c}\text { Students } \\
\text { accepted } \\
\text { 2018/2019 } \\
\text { (Regular } \\
\text { training } \\
\text { /Distance } \\
\text { learning) }\end{array}$ & $\begin{array}{c}\text { Students } \\
\text { accepted } \\
\text { 2019/2020 } \\
\text { (Regular } \\
\text { training } \\
\text { /Distance } \\
\text { learning) }\end{array}$ & $\begin{array}{c}\text { Plan } \\
\text { reception } \\
\text { 2020/2021 } \\
\text { (Regular } \\
\text { training } \\
\text { /Distance } \\
\text { learning) }\end{array}$ \\
\hline \multicolumn{7}{|c|}{ "Bachelor" } \\
\hline $\begin{array}{l}3.4 \\
\text { Social activities }\end{array}$ & 1,05 & $120 / 60$ & $20 / 5$ & $19 / 1$ & $20 / 9$ & $20 / 10$ \\
\hline $\begin{array}{l}3.7 \\
\text { Administration and } \\
\text { Management }\end{array}$ & 0,75 & 550 & $40 / 0$ & $26 / 38$ & $20 / 29$ & $20 / 20$ \\
\hline $\begin{array}{l}3.8 \\
\text { Economics } \\
\end{array}$ & 0,65 & 220 & $15 / 7$ & $0 / 0$ & $0 / 0$ & $0 / 0$ \\
\hline $\begin{array}{l}.13 \\
\text { General engineering }\end{array}$ & 1,20 & 800 & & & & \\
\hline $\begin{array}{l}\text { Industrial } \\
\text { Management }\end{array}$ & & & $20 / 20$ & $20 / 20$ & $26 / 19$ & $25 / 20$ \\
\hline \multicolumn{7}{|c|}{ „Master” } \\
\hline $\begin{array}{l}.4 \\
\text { Social activities }\end{array}$ & 1,05 & 40 & $0 / 13$ & $0 / 9$ & $0 / 10$ & $0 / 12$ \\
\hline $\begin{array}{l}3.7 \\
\text { Administration and } \\
\text { Management }\end{array}$ & 0,75 & 200 & $4 / 50$ & $0 / 67$ & $0 / 58$ & $0 / 60$ \\
\hline $\begin{array}{l}3.8 \\
\text { Economics } \\
\end{array}$ & 0,65 & $0 / 0$ & $0 / 0$ & $0 / 0$ & $0 / 0$ & $0 / 0$ \\
\hline \begin{tabular}{|l|}
5.13 \\
General engineering
\end{tabular} & 1,20 & 340 & & & & \\
\hline $\begin{array}{l}\text { Industrial } \\
\text { Management }\end{array}$ & & & $12 / 0$ & $12 / 16$ & $14 / 6$ & $16 / 8$ \\
\hline
\end{tabular}

Table 1 presents "Proposal for admission plan for students by years of Technical University - Gabrovo, Faculty - Business" for which the state provides funds for their tuition support in the professional directions of the Faculty of Business for the academic year 2018/2019, 2019/2020 and 2020/2021. This proposal was made after implementation of Decree No. 64 of 25 March 2016, which is restrictive. The vocational fields in which admission has been reduced over the last 3 years will decrease and will decrease in the following years, but the number of students enrolled in them may not be below 15, according to the Ministry of Education and Science. If this happens, the Ministry of Education and Science will suspend the approval of state-funded admission (this is also evident from Table 1 for section 3.8 "Economics" of TU Gabrovo). This phenomenon is observed mainly in professional fields, which are not inherent in the traditional profile of higher education. These are 
"Economics", "Administration and Management", "Social Activities", created in the last 2 decades. Analyzing the data in Table 1, we can say that: for the academic year 2018/2019, 2019/2020, 2020/2021 there will be admission in the fields 3.4 "Social activities", 3.7 "Administration and management" and 5.13 "General engineering"; and for 2021/2022 5.13 General Engineering State Reception.

In the areas of the first group (Mathematics, Chemical and Physical Sciences, Energy) we have the most undeserved low demand. This is evident from the rating system - a small or very low number of students, on the one hand, and very good conversion rates, including high income of graduates, on the other.

As a general conclusion from the editions of the rating system we can say that the students with the highest professional degrees (informatics and computer science, mathematics, medical professional fields, a number of technical professional fields) have the highest incomes and the highest achievement rates. It can be expected that these will also be the professional areas with the highest future income growth.

One of the most significant challenges in the system of pre-school and school education is to provide pedagogical specialists in the long term, because after 5 years there will be a shortage of 40 thousand educators.

In accordance with the National Strategy for the Development of Research adopted by the National Assembly of the Republic of Bulgaria, budget expenditures for science in 2018, 2019 and 2020 have been increased with additional financial resources of BGN 15 million for each year. This appropriation is directed to public return activities for research related to significant public or sectoral tasks.

The Ministry of Education and Science offers free education in priority majors, introducing free training in them to reduce staff shortages. The aim is to stimulate interest in the specialties that will be most needed in the labor market in the future and in new professions.

The tuition fees for students in the fields of pedagogy, mathematics, chemical sciences, physical sciences, religion, materials and materials science from the academic year have been completely dropped from 2018/2019. At the same time, state funding may be suspended for 15 non-priority majors, including Economics, Administration and Management. This also applies to destinations that do not fit into the profile of a university. In all Higher education institutions in the Republic of Bulgaria, where there is no approved state admission, students may be trained in these non-priority majors but in paid admission. The branches of universities in poor regions of the country are additionally funded, such as: Vratsa, Vidin, Smolyan and Kardzhali - in order to preserve higher education there and not depopulate the region. 
The statistics clearly show that no higher education institution in Bulgaria was able to complete its admission in the 2017/2018, 2018/2019 and 2019/2020 academic years. There is a tendency for the total number of places to be announced at universities to be higher than the number of students leaving school.

\section{Some decisions about the lack of sufficient candidate students}

About 23,000 locations across the country remain vacant. The vacancies at the Sofia University "St. Kliment Ohridski" are 1500, and the pre-planned ones are close to 7000. The record is at the University of Economics in Varna, where nearly 2000 student places have remained unfulfilled - almost half of the plans. At the Technical University of Gabrovo, the situation is the following: an approved admission of 719 and an admission of 739 students. Here is a place to note the new forms of training:

- External training (at the place of work - ABB Sevlievo, Ideal Standard - Sevlievo, Arkus - Lyaskovets);

- Special regime (when a full-time student starts working on a basic employment contract, he / she completes a package of documents and can attend extramural studies with students and take their exams with the full-time students);

- Facilitated regime (when the student has changed status, such as pregnancy, young children, etc., then the classes are with the extras and the exams are with the regular training);

- Individual mode (when the student wants to graduate early but must have successfully completed the second year and with very good success 4.50 , two years for one are taken).

\section{Conclusion}

The following major conclusions can be drawn:

- funding schemes are being improved to increase population participation in the higher education system;

- $\quad$ increase efficiency and optimize the use of resources;

- $\quad$ progressively increasing the number of students, which creates the risk of deterioration of the quality of education, which in turn necessitates the establishment of quality control and assessment systems, systems for the success and efficiency of the educational process;

- increasing the level of correspondence between education and the needs of the labor market is achieved through closer cooperation between educational institutions, employers and scientific institutions;

- improving financial security by raising education and training costs; 
Proceedings of the International Scientific Conference. Volume II, May $22^{\text {th }}-23^{\text {th }}, 2020.214-226$

- $\quad$ the accreditation system is being improved;

- the costs are linked to the quality of education and the results achieved;

- $\quad$ new forms of training are sought and

- digitalization in the educational process.

\section{References}

Boeva, V. (2013). Partnership of Technical University - European Challenges and Tendencies. Journal of the Technical University of Gabrovo, 45, 93-96.

Kartunov, St. (2015). Model na obuchenie po tehnologichnite disstiplini $v$ injenernite specialnosti na TU. Gabrovo, Unitech, 380-385.

Kartunov, S., \& Petrova, D. (2009). Educations - development innovation of program „Nanomicrosystems and electronics technique“. $26^{\text {th }}$ Symposium on Advances in Experimental Mechanics, 103-105.

Nacionalna strategia za razwitie na nauchnite izsledvania (2009-2019). Retireved from http://eur-lex.europa.eu/LexUriServ/LexUriServ.do?uri=COM:2010:2020:FIN:BG:PDF

Petrova, D., \& Lazov, L. (2010). New Technologies Approach to E-Learning and Succesful Presentation, $39^{\text {th }}$ IGIP Symposium, Joint International IGIP-SEFI Annual Conference 2010, 552-561.

Stoyanova, M. (2008). Obnovenata Lisabonska programa na Evropejskia Saiuz za investirane v znania I inovacii 2008-2010//INFO sviat, № 3.

Zakon za razvitieto na akademichniq sastav v Republika Balgaria, DV, № 38 ot 21.05.2010, № 81 ot 15.10 .2010 , № 101 ot 228.12.2010 Retrieved from http://old.government.bg/ cgi-bin/ecms/vis 